\title{
蓋深形成術施行後の治瘾経過に関する実験的研究
}

\author{
須永芳弘
}

\section{An experimental study of healing process after palatal vault osteotomy}

\author{
Yoshihiro SunAga
}

\begin{abstract}
To elucidate postoperative healing at the lateral site of palatal vault osteotomy by the modified method of Yoshizawa and Takahashi, operation was conducted experimentally on 25 adult dogs. One or two months later, the site was examined by soft X-ray radiography and contact micro-radiography, and ground sections of undecalcified bone specimens were examined after Cole's hematoxylin-eosin stain and Villanueva bone stain. These sections were then subjected to bone histomorphometry.

The direction of bone growth on cut surfaces varied depending on the postoperative arrangement of segments of hard palate bones separated by osteotomy. New bone formation proved to begin at a point where the space between the interior and exterior cut ends were narrowest. In hard palate segments, bone resorption was noted on the nasal surface, and bone formation, on the oral surface.

The shape of a cut end of the original bone was classified into 4 types, and newly formed bone, into 5 types. With the exterior cut end of the original bone, most commonly, the upper part of the cut end projected (upper projecting type), and new bone formed over the projecting surface (upper forming type). With the interior cut end of the original bone, the type such that the lower part of the cut end projected (lower projecting type) was usually found, and new bone mostly formed over the projecting surface (lower forming type), except in the case of the no forming type.

Bone histomorphometry was carried out as 3 parameters, new bone volume, corrected new bone volume and mineral appositional rate. New bone volume on an exterior cut end was greater than that on an interior cut end. The volume 2 months after osteotomy was greater than that at 1 month. Corrected new bone volume on the exterior cut end was almost the same as that on the interior cut end. The mineral appositional rate 1 month after osteotomy was slightly faster than that at 2 months. The rate on the exterior cut end was faster than on the interior cut end.
\end{abstract}

Key words: palatal vault osteotomy (口蓋深形成術), bone morphometry (骨形態計測), healing process (治疮過程)

山形大学医学部楝科口腔外科学講座

（主任：吉澤信夫教授）

Department of Dentistry and Oral Surgery, School of Medicine, Yamagata University (Chief: Prof.

Nobuo Yoshizawa)

受付日：平成 3 年 4 月 30 日
緒

言

上顎歯㡟堤の萎縮が著明で，硬口蓋が平坦になった患 者では，通法にしたがって総義齿を作製，装着しても良 好な維持, 安定を得ることはきわわて困難である。この 
ような证例に対して，歯槽堤形成術を応用する場合，特 に義崡の前方への滑脱および前後的動摇を防止するため には，口蓋深形成術が有効である。

本手術の原法は，1931年に Wassmund ${ }^{1}$ が発表したも ので，その術式は，まず両側の上顎結節を結ぶ菌槽頂の 内側にU字形の粘膜骨膜切開加兄，両端には口腔前庭 側に及ぶ綐切開を追加しておく，そして唇類側の骨膜剝 離を行って，梨状口の下部を露出したのら，ここから鼻 中隔下部の揳状切除を行う。次に口蓋側粘膜骨膜をわず かに㔀離し，バーと骨ノミを用いて切開線と平行な骨切 りを施す。ただし硬口蓋後縁部恰切りをせずに，ここ を支点として硬口蓋を鼻腔側に圧迫挙上して前歯，小曰 歯部の相対的歯槽堤の高さの增加をはかる．その後，唇 煩側の粘膜骨膜弁を，梨状口下縁を含む上方で縫合固定 し，2 次的上皮化汇上る口腔前庭形成術を行ったのち， 口蓋側に打いては減張した升を旧位に戻して骨切り部を 被覆するすのである，術後は床あるいは義歯を利用した 固定を $2 \sim 3$ 週行い， 6 週目に新義雪を作製する.

Wassmund 以後はしばらく追試されなかったが，1976 年になり, Charest と Goodyer ${ }^{2}$ が歯槽堤のU字形の切 開線江平行な骨切りを行って，この骨片を前方から口腔 側に倒し，そこにできた間隙から鼻中隔下部を切除寸る 方法を発表しており，Leonald と Howe ${ }^{3)}$ 同様の方法 を報告した。すた1978年にはSteinhäuser"4)が，硬口蓋の 正中部に 2 本の矢状骨切りを行って，鼻腔粘膜を広く剝 離することなく鼻中隔下部の切除を行っている，最近て は，1986年に Tiner ら5が Wassmund の術式に工夫を 加光て報告している.

一方，本邦では1981年に吉澤ら が，その著者のひと りである高橋が考案した Charest らの術式の改良法（以 下，吉沢一高橋の方法と称す）を硬口蓋正迫術として発 表し，その臨床応用例を報告した。この方法は雪槽頂内 側の骨切り後，正中口蓋縫合部《 1 本の矢状骨切りを加 えて硬口蓋と鼻中隔の結合を断ち，ここから鼻中隔下部 の切除を行うむのである.現在本邦では,この吉澤一高橋 の方法が一般的に行われている 硬口蓋正中部からのアプローチにより番腔粘膜の賣傷が 少ないため，他の方法に比べて十分な血流が確保できる こと，また硬口蓋骨片が左右に分けられるため，口蓋穹 の形態付与飞際して調節が 可能なことなどが考光られ る。しかし組織学的な治嘴についての研究は行われてお らず，特に術後の骨片の安定性が羲菌の維持と安定に関 与することから，著者は骨切り部の結合状態に対して関 心を持っに至った。

そこで本研究では，吉澤一高橋の方法に準した口盍深 形成術を成犬に施し，骨切り部の治搅経過について，X 線学的ならびに組織学的に観察するとともに，骨形態計 測の手法を用いて定量的に検討を行った。

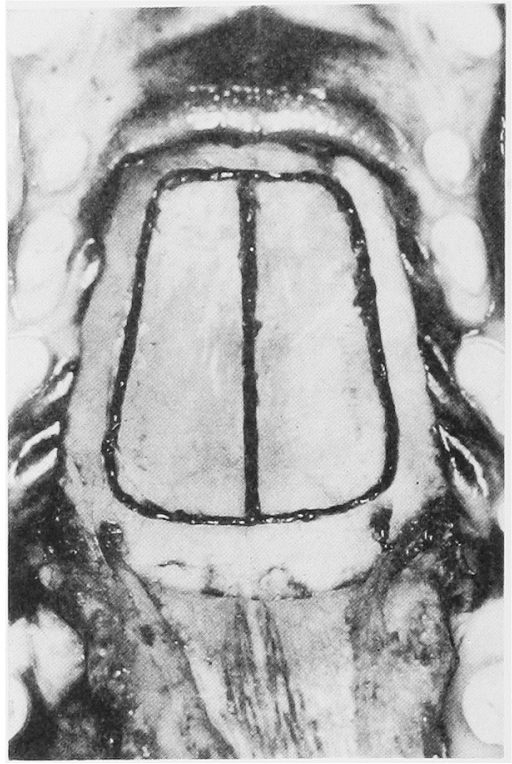

写真 1 術中写真 (口蓋の骨切り)

\section{研究 方 法}

\section{1. 実験動物}

実験には，雌雄の別なく，永久齿列の完成した平均年 龄 2.2 歳で体重 $10 \mathrm{~kg}$ 前後の雑種成犬 27 頭を用いた。 ち2 頭は対照群 (非手術群) とした。

\section{2. 口蓋深形成術の術式}

手術は，5\% sodium pentobarbital $0.5 \mathrm{ml} / \mathrm{kg}$ による 静脈麻酔扣よび $\mathrm{GO}$ 吸入麻酔下に实施した。まず，歯列 とほ添平行なU字形の切開を加点て，大口蓋神経血管束 を含む粘膜骨膜弁を大口蓋孔が露出するまで劋離し，反 転した，次にフィッシャーバーを用いて，鼻腔粘膜の損 傷に注意しながら切開線と平行な骨切りを行ったのち, 口蓋正中部にも骨切りを加光，鼻中隔下端を明示した （写真 1)。ここから鼻中隔下部を破骨鎮子とバーにより 除去し，鼻腔粘膜の付着した骨口蓋を上方に圧迫してロ 蓋の深化を図った，その後、口蓋升を旧位に戻し，縫合 を行った．固定には即時重合レジンを適合させてプレー トを作製し、これを stainless steel wireを用いて歯牙拉 よび歯槽骨に結紮した。

\section{3. 実験期間およびその間の処置（図 1)}

手術の際之同様の麻醉下に，術後 1 か月（4週）でブ レート孝除去し，同日または術後 2 か月（8週）で上䫑 部を摘出した。そその後心臓を穿刺し，10\%中性ホルマリ ンを注入して屠殺した。な持屠殺前にオキシテトラサイ クリン（以下OTC と略す）を背部に皮下注射し，2回 骨標識を行った。 


\begin{tabular}{|c|c|c|}
\hline 手術 & 術後 1 力月 & 術後 2 力月 \\
\hline 1 加月群 。- & ]$_{t t+1 t t} \infty$ & \\
\hline 2か月群 ○一 & -0 & $\mathrm{Hft} \mathrm{ttt}_{\bullet}$ \\
\hline
\end{tabular}

图 1 実験期間とての間の処置 ○：硬口蓋王迫術（口蓋深形成術） (ㅇ)：プレート除去

○：上顎部摘出

$\uparrow \uparrow \uparrow \uparrow \uparrow \uparrow: 2$ 回骨標識（OTC 3 日一休薬 7 日 -OTC 3 日)

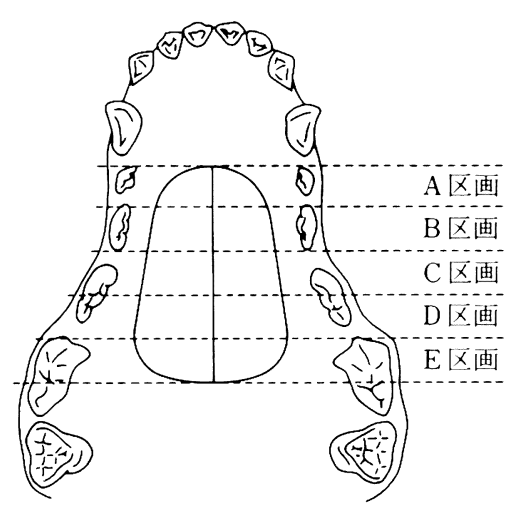

図 2 軟X線写真観察のための上顎部の分割

\section{4. 試料の作製ならびに観察方法}

\section{1) 軟X楾写真による観察}

術後1か月もしくは2 か月目に摘出した上顎部の軸位 における軟X線写真を撮影し, 左右の歯列弓と平行に施 した骨切り部の骨性結合の有無について肉眼的に観察し た。

軟X線発生装置は Softex CSM-2型（ソフテックス社 製）の CMB 側を用いた。

観察にあたっては，骨切り部を前方から後方に向かっ て A，B，C，D拈よび Eの 5 区画に分割し（図2）， それぞれの両側の骨切り部において骨性結合の有無を検 討して，点数化した。すなわち 1 区画で雨側に骨性結合 を認めるものを2点，左右いずれかに認めるものを 1 点, 雨側とも認めないものを 0 点とし， 1 頭ごとの合計 点数を求めた。

2) 非脱灰研磨標本を用いた観察

（1）非脱灰研磨標本の作製法（図 3)

上顎部を軟X線写真の観察の際と同様に 5 区画に分 け，組艤片として切り出した。

A， C， Eの組織片は10\%中性ホルマリンで4 日間以
手街（硬口蓋圧迫衍）

——OTCによる骨標識

屠殺(上顎部摘出)

|……軟 $\mathrm{X}$ 線写真

組織片（A, B , C , D , E ) の切り出し

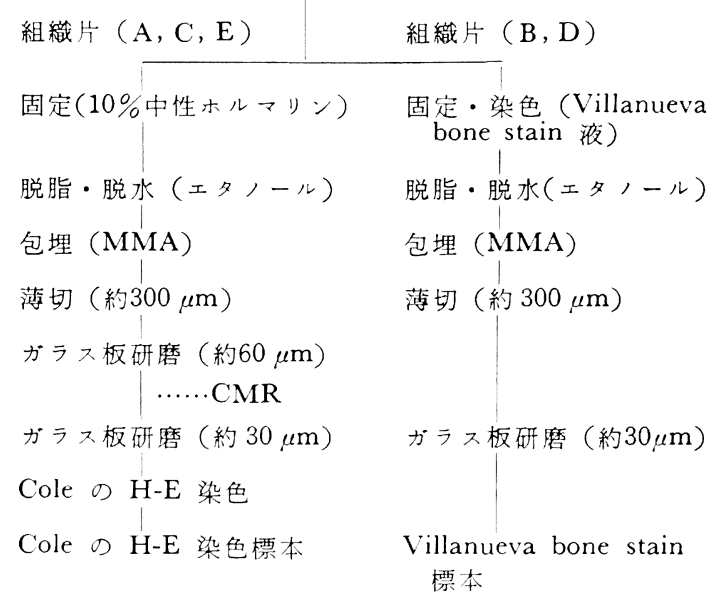

図 3 非脱灰研磨標本の作製手順

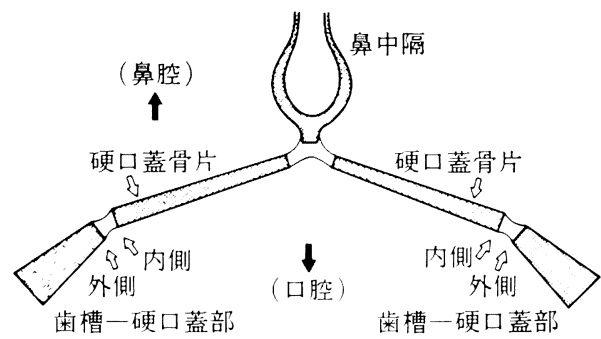

図 4 鏡検部位（介で示した部位）

上固定し，エタノールによる脱脂，脱水の系列を経て， methyl methacrylate (以下 MMA と略す) にて包埋し た。そしてクリスタルカッター MC'-202（マルトー社 製）を用いて，厚さ約 $300 \mu \mathrm{m}$ の薄切片を切り出した。 その後, 本間ら ${ }^{10)}$ の方法に準じてガラス板研磨を行い, 爫 $60 \mu \mathrm{m}$ の均等な厚さになったところで, コンタクトマ イクロラジオグラム(以下 CMR と略す)撮影用の標本と した。それからふたたびガラス板研磨を行って約 $30 \mu \mathrm{m}$ 厚になったところで, Cole11) のへマトキシリン・エオ シン（以下 H-E と略す）染色を施した。

一方，B，Dの組織片は，新鮮なままVillanueva bone stain ${ }^{12)}$ 液中に 4 日間浸して，固定および染色を行 ったのち，同様に包埋した。硬化したブロックから約 $300 \mu \mathrm{m}$ の薄切片を切り出し, 䄪 $30 \mu \mathrm{m}$ 厚になるまでが ラス板研磨を施した。

(2) CMR の観察 

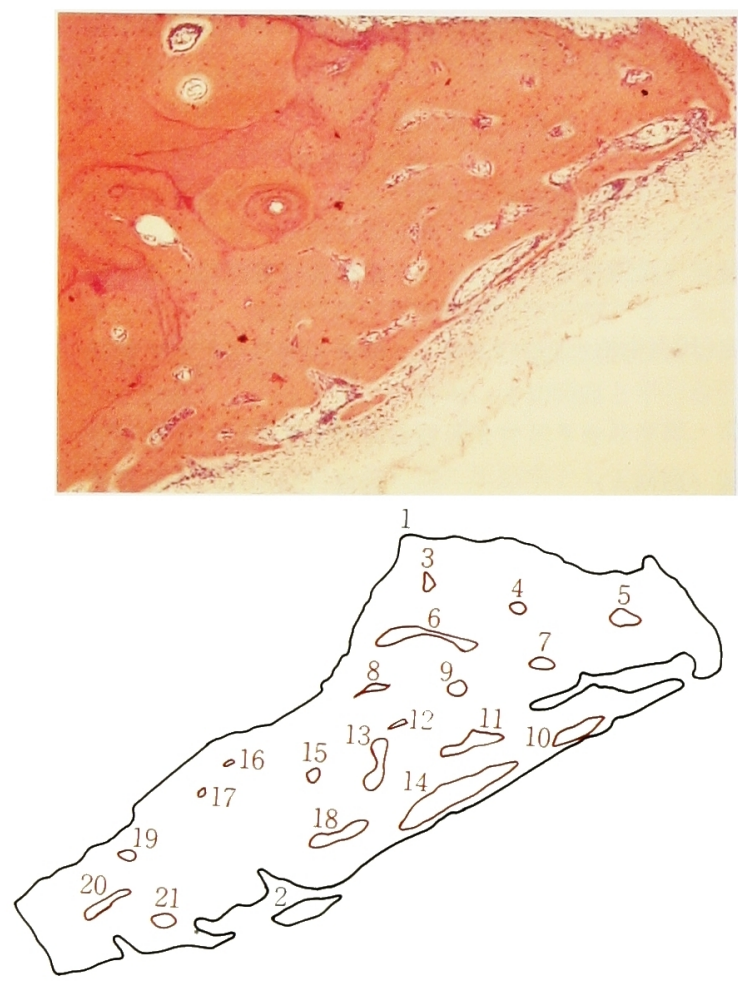

TOTAL AREA $=13868.614 \mathrm{~mm}^{2}$

$\begin{array}{rlr}1: 14702.370 & 11: 70.640 & 21: 38.495 \\ 2: 118.460 & 12: 7.030 \\ 3: 12.355 & 13: 70.180 \\ 4: 16.550 & 14: 266.825 \\ 5: 42.465 & 15: 17.115 \\ 6: 104.850 & 16: 4.395 \\ 7: 26.030 & 17: 4.025 \\ 8: 18.530 & 18: 74.375 \\ 9: 25.345 & 19: 15.470 \\ 10: 80.980 & 20: 58.560\end{array}$

図 5 新生骨面栍の測定

上: Cole の H-E 染色像

下：画像解析に上る新生骨面積の測定

CMR は, Softex CS.I-2 型（ソフテックス社製）の CMR 側を用いて撮影し, 切離した左右の硬口蓋骨片お よび雨槽一硬口蓋部（図 4)で鏡検した。

(3) 骨切り部の組織学的钼察

Cole の H-E 染色と Villanueva bone stain を施し た非脱灰研磨標本について，硬口蓋骨片扣よび歯慒一硬 口蓋部で鏡検した。

（4）新生骨面眚㧍よび補正新生 骨 面積の測定
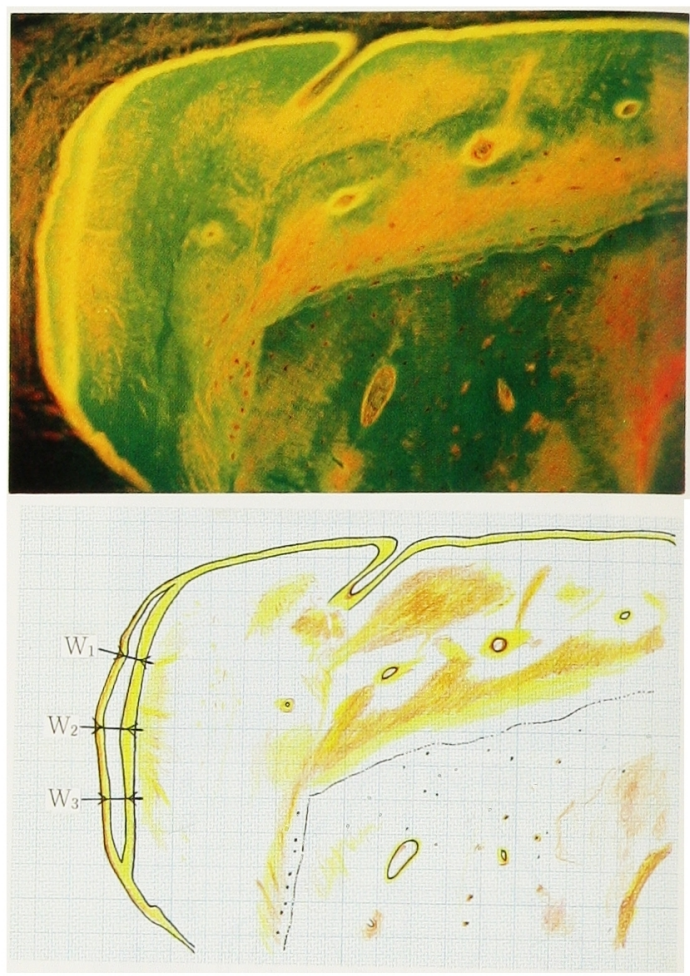

図 6 類骨層石灰化速度の測定 上: Villanueva bone stain 螢光像 下：描画像からの測定法

$$
\begin{aligned}
& \mathrm{W} ; 2 \text { 重骨標識問の距離 } \\
& W=\frac{W_{1}+W_{2}+W_{3}+\cdots+W_{n}}{n}
\end{aligned}
$$

類骨層石灰化速度 $(\mu \mathrm{m} /$ day $)=\frac{W}{10} \times \frac{1}{200}$

骨切り部に打ける新生骨の面積（以下新生骨面積と称 する）の測定には，Cole の H-E 染色標本を用いた。 ず Cole の H-E 染色標本の左右の歯慒一硬口蓋部を 200 倍で描画し，それぞれの骨切り断端部の新生骨に相当寸 る面積を, 画像解析ソフトを入力した汎用コンピュータ 一V Vax 11 亿上り求めた（図 5)。これを実際の標本上 での数值に換算し，新生骨面䆄とした。

さらに，それぞれの骨切り断端部の厚径を計測し，前 述の新生骨面䅡をその值で除して $1 \mu \mathrm{m}$ 幅の断端に佂け る平均の新生骨面積（以下補正新生骨面積と称する）を 算出した。 そして, Cole の H-E 染色標本から観察され

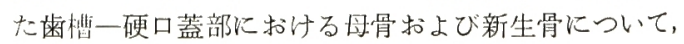
後述の上らな形態分類を行らとともに, 補正新生骨面積

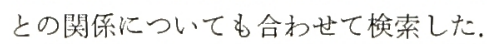

（5）類骨層石灰化速度の測定

類骨層石灰化速度はVillanueva bone stain 標本の䖝 光像から求めた。 ず左右の歯槽一硬口蓋部を, 落射型 

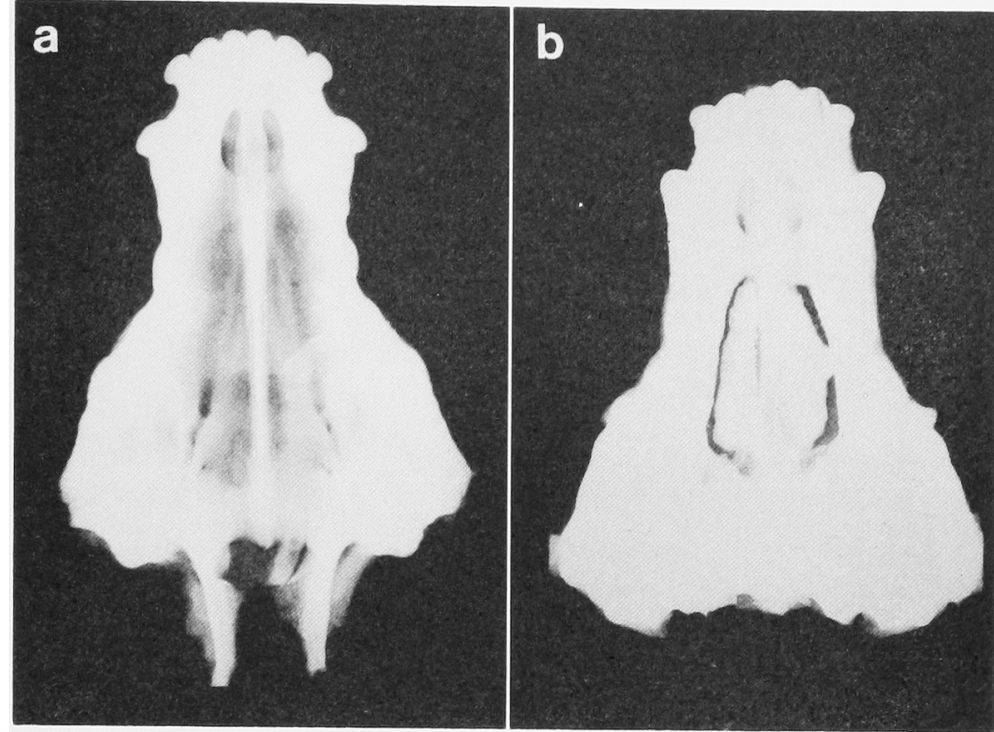

写真 2 㰸 $\mathrm{X}$ 線写真

a : 対照群; 口蓋裂, 大口蓋孔, 小口蓋孔小 X線透過像として認められ, 口 蓋溝す周囲よりもや※X線透過度が低い像として認められる $(25 \mathrm{KVp}$, $13 \mathrm{~mA}, 20 \mathrm{sec}$ ).

b：2か月群；一部で骨性結合を認める $(20 \mathrm{KVp}, 10 \mathrm{~mA}, 15 \mathrm{sec})$.

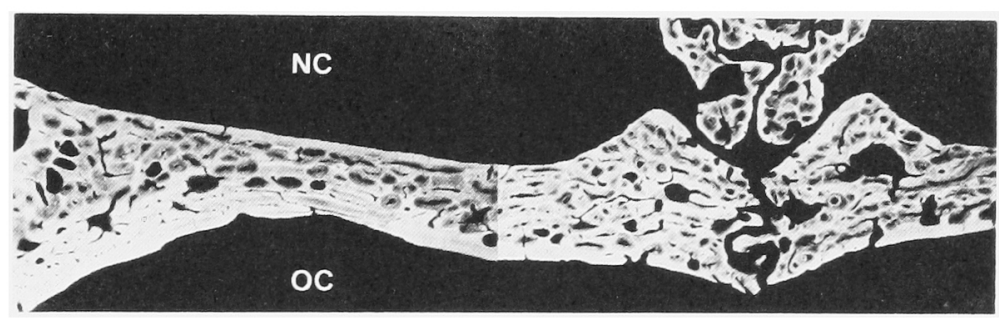

写真 3 硬口蓋の CMR 像（対照群）

C区画の正中部から右側菌槽部沉加ての前額断。左在の上顎骨々鍸骨で正 中口蓋䋖合を形成している，口蓋は口腔 (OC) 面, 鼻腔 $(N C)$ 面とも平坦 である(×4).

表 1 龂 X缐写真による骨性結合の評価

\begin{tabular}{c|ccccc|cc|c}
\hline 実験群 & A区画 & B 区画 & C区画 & D区画 & E 区画 & 合 & 計 & 頭平均 \\
\hline 1 か月群 (11頭) & 2 & 1 & 2 & 1 & 0 & 6 & 0.5 \\
2 か月群 (10頭) & 9 & 8 & 7 & 4 & 7 & 35 & 3.5 \\
\hline
\end{tabular}

篮光顕微鏡で観察し，描画装置にて 200 倍で描画した。 そして骨切り断端部において，OTC が 2 重に標識され

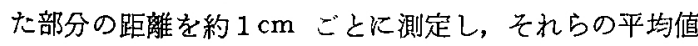
と標識日数，休薬日数から算出した（図6）。
なお，本研究における各種計測值については，相互に

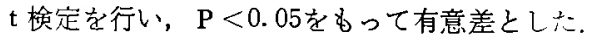




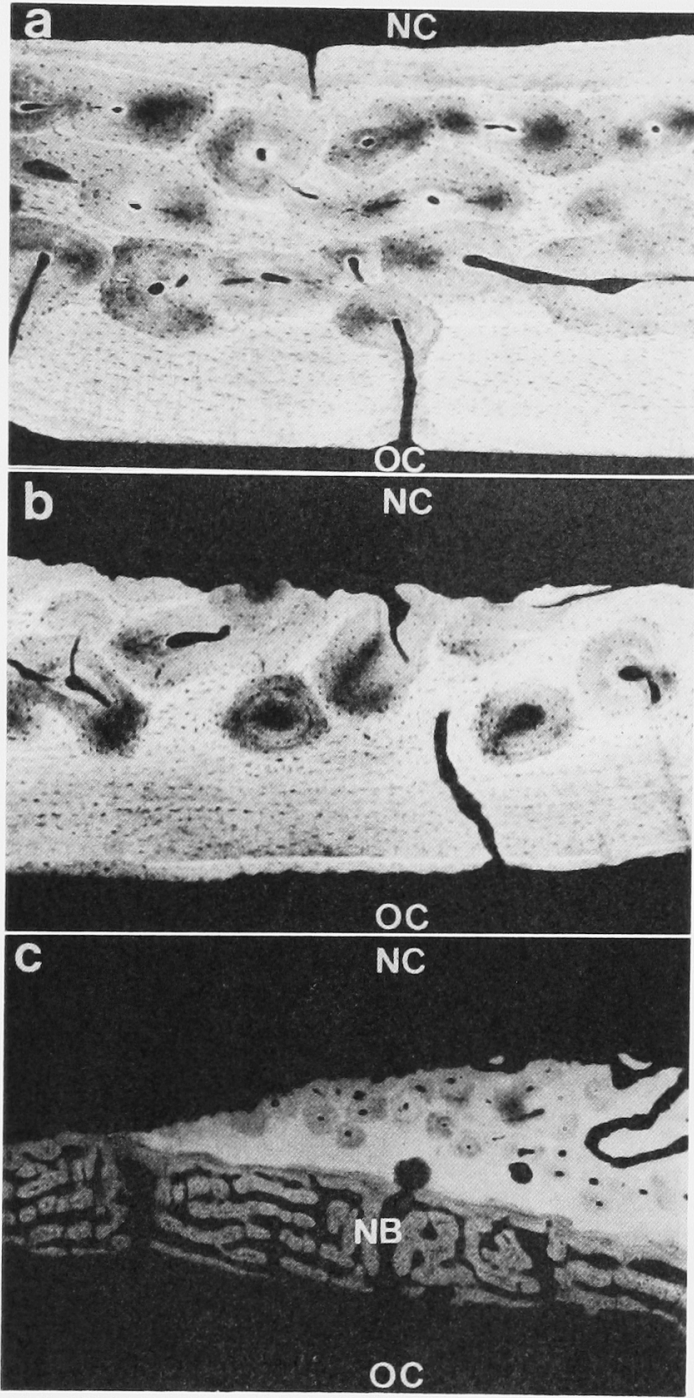

写真 4 硬口盐骨片の CMR 像

a : 対照群; 鼻腔と口膑側に啳板がみられ，両 者の間にはハバース層板と介在層板が存在して いる $(\times 25)$.

b : Iか月群; 舅腔側の基礎層板が消失している $(\times 25)$.

c 2 か月群；鼻腟面は吸収のため凹凸不整だが， 口腔側にはX線透過度の低い新生骨 (NB) 認 める $(\times 10)$.

\section{研 究 成 績}

\section{1. 軟 $\mathbf{X}$ 線写真の所見}

対照群では，X線不透過性を示すものとして畺中隔基 部が認められ，X線透過性のものでは口蓋裂（切粀孔）,

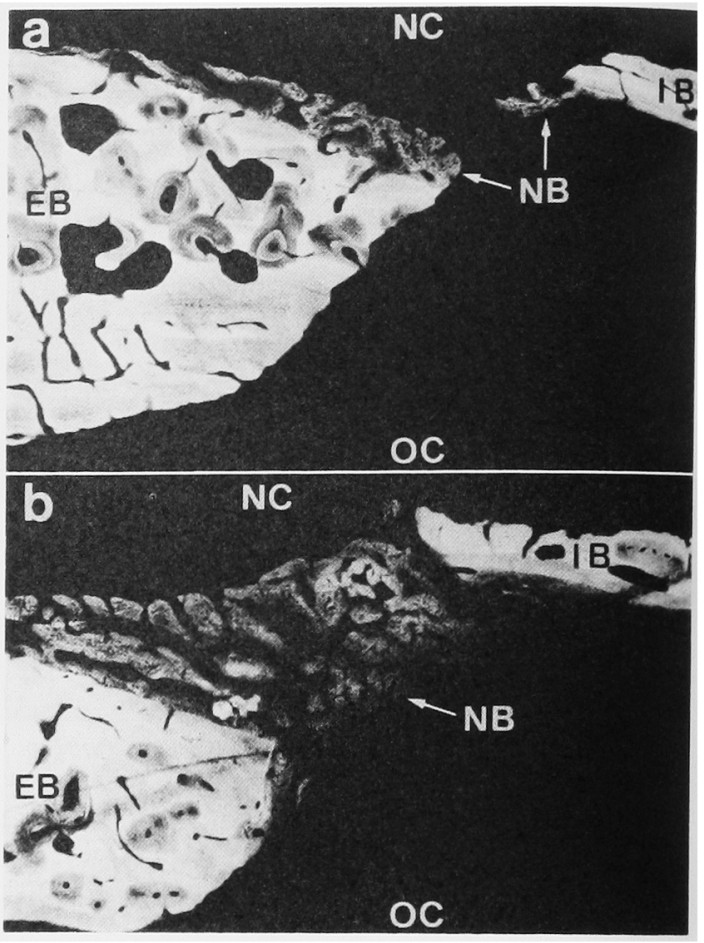

写直 5 菻槽一硬口蓋部の CMR 像（1 か月群）

$\mathrm{a}$ ：線稚性結合部; 外側断端部の盘腔而々, 内側断 端の口腔面に新生骨 (NB) を認める $(\times 10)$.

b : 骨性結合部; 外側断端の鼻腔面と内側断端の口 腔面との間に骨性結合 (NB 部)を認める $(\times 10)$. $\mathrm{EB}$; 外㑡 (畨槽部) 骨片, IB ; 内側 (硬口蓋部) 骨片

大口蓋孔，小口蓋孔が 観察された。さらに横口蓋絴合 が，左右の大口蓋孔を通過するX線透過性の線として認 められた（写真 2 a).

1か月群は骨性結合の所見にそしく，また硬口蓋骨片 には骨吸収を思わせるX線透過性の部分を認めるものが 多かった，一方 2 か月群では，動物間で所見の差があり 部分的な骨性結合を認めるもの（写真 2 b) や全く結合 のないものが観察された，骨性結合の有無を点数化した ところ，1か月啡が 0.5 点， 2 か月群が 3.5 点であった (表1).

\section{CMR の所見}

1）硬口蓋骨片

対照群の口蓋中央部の前額断における所見では，禹中 隔 (鋤骨) と左右の上頻骨の口蓋突起が中央で合し，正 中口蓋縫合を形成しているのが認められた（写直了）.

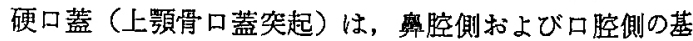
碟層板とその間に位䈯するハバース層板，介在層板が認 められ，3層構造を呈していた（写直 $4 \mathbf{a}$ ）。

1 か月群では舫腔側基礎層板の消失傾向を認め，ハハ 

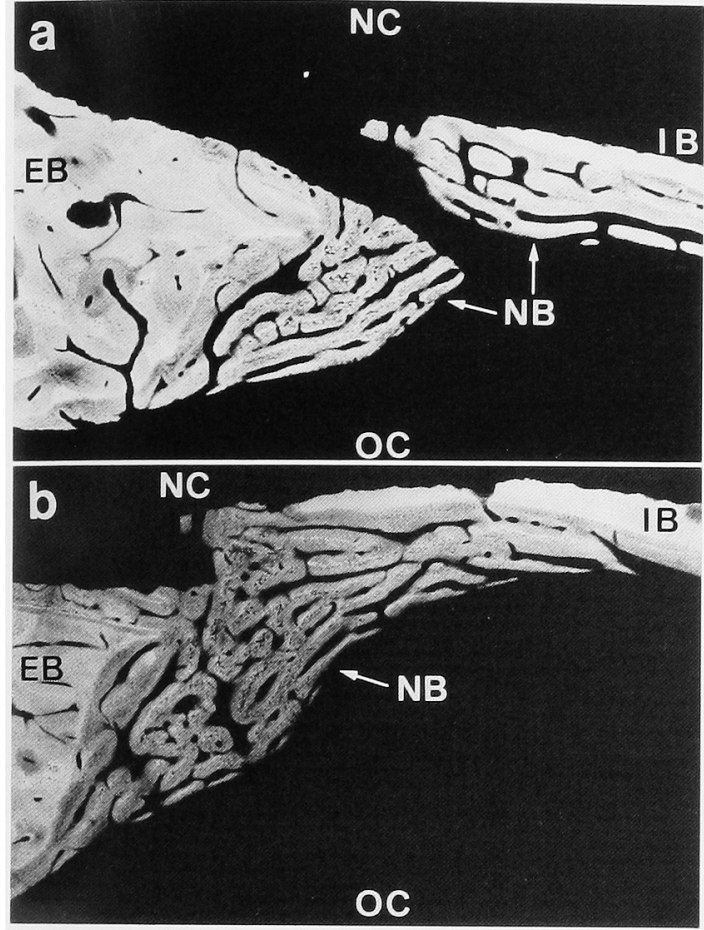

写真 6 甚槽一硬口蓋部の CMR 像 ( 2 か月群)

a：線維性結合部；外側断端部は切断面を中心见, 内側断端部は口腔面からの新生骨 (NB) を認め る $(\times 10)$

$\mathrm{b}$ ：骨性結合部；外㑡断端部の切断面および禹腔面 と内側断端部の口腔面との間飞骨性結合 (NB 部)を認める $(\times 10)$

一ス㬝板と介在層板は鼻腔側に露出し，凹凸不整の表面 形態を呈していた， 口腔側では基礎層板が認められた (写真 $4 \mathbf{b}$ ).

2 か月群では，1か月群と同様に宜腔側基礎層板の消 失や鼻腔に面したハバース層板之介在層板の吸収像がみ られた，一方口腔側ではほとんど変化がないか，もしく は大小不同の骨小腔を含むX線不透過度の低い梁状の骨 形成を認め，八バース管の拡大を示するのも観察された (写真 $4 \mathbf{c}$ ).

2) 歯槽一硬口蓋部

1か月群の外側断端部における骨切り面（以下外側切 断面上称する）は，凹凸不整で骨吸収が示㗘された，新 生骨は不規則な配列をした大小不同の骨小腔を含み，鼻 腔面の基礎層板から内側断端部に向から梁状のX楾不透 過像として観察されたが，その量はわずかであった。内 側断端部に批ける骨切り面 (以下内側切断面之称する) も凹凸が目立ち，新生骨は外側断端部以上に少なく（写 真 $5 \mathbf{a}$ ), 骨吸収の及の像を呈しているものが多かった。 な打 1 か月群の一部には，外側母骨の鼻腔面と内側母
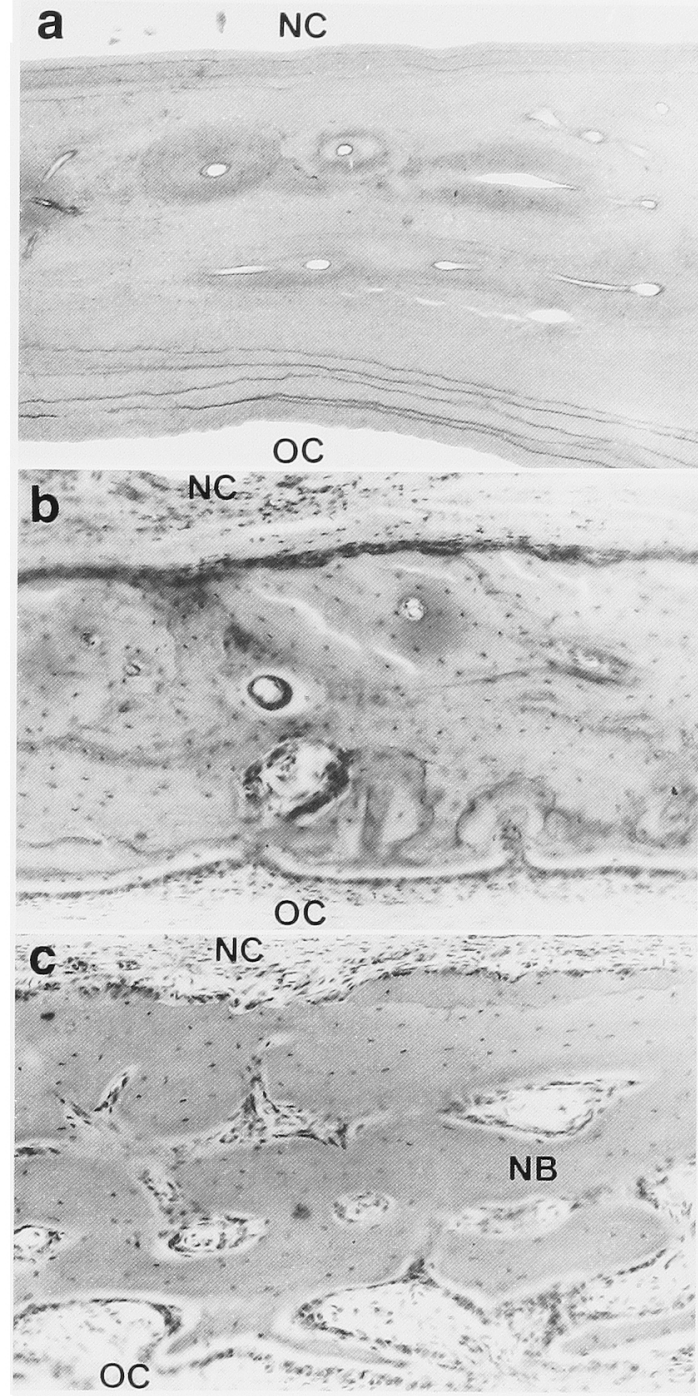

写真 7 硬口蓋骨片の Cole の H-E 染色像

a：対照群；奥腔側と口腔側の基礎層板と，その間 のハバース層板および介在層板を認める $(\times 25)$ 。

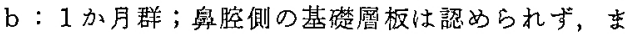
た口空側でも層状構造が不昉嘹になっているが 類骨々骨芽稩胞の配列を認める $(\times 50)$.

c・2 か月群；母骨は写真の右上方にわずかに認め るのみで，硬口蓋骨片は注とんどが類骨を伴っ た新生骨 (NB) 加なる $(\times 50)$.

骨の口腔面とを結ぶX線不透過度の低い新生骨で架橋ざ れた骨性結合部が認められた（写真 $5 \mathbf{b})$.

2 か月群の外側断端部の新生骨は，鼠腔面之切断面沗 ら添加され，梁状のX線不透過像が㺓み重なるようにし て内側断端部に向かって件びて括り，そのX行透過度 は1か月群よりもやや高かった。また骨小腔の配列は不 

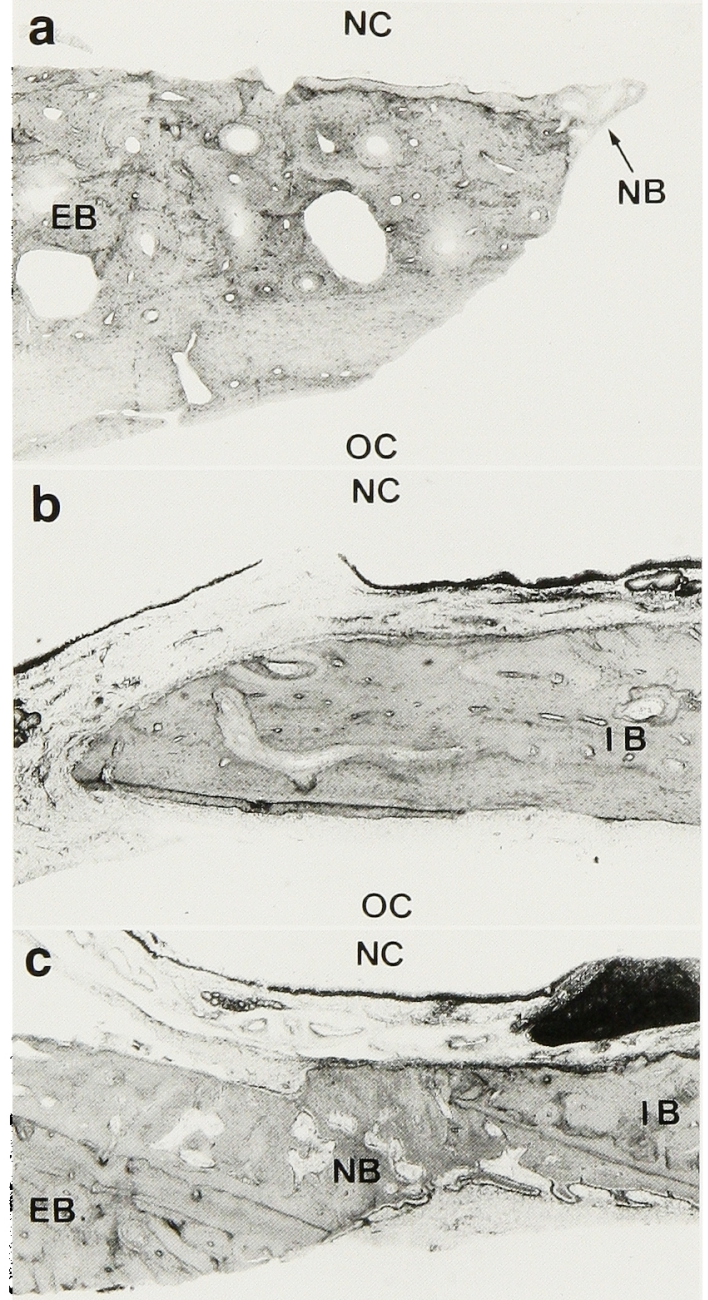

OC

写真 8 橉槽一硬口蓋部の Cole $の \mathrm{H}-\mathrm{E}$ 染色像 ( 1 加月群)

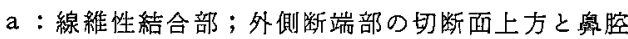
面からの新生骨 (NB) を認める $(\times 10)$.

$\mathrm{b}$ ・線維性結合部; 内側断端部に新生骨を認めない ( $\times 10)$.

c . 骨性結合部; 外侧断端部の鼻檫面々内側断端部 の口腔面の間で骨性結合 (NB 部)を認める( 10).

規則であるものの，形態と大きさは揃いつつあった。内 側断端部では骨形成のないものも多かったが，新生骨を 認めるものは，ほとんどが口整面から外側断端部に向か って形成さ礼ていた（写真 $6 \mathbf{a}$ )。

骨性結合は 2 か月群で増加し，外側では切断面および 番腔面から，内側では口腔面からそれぞれの面と平行に

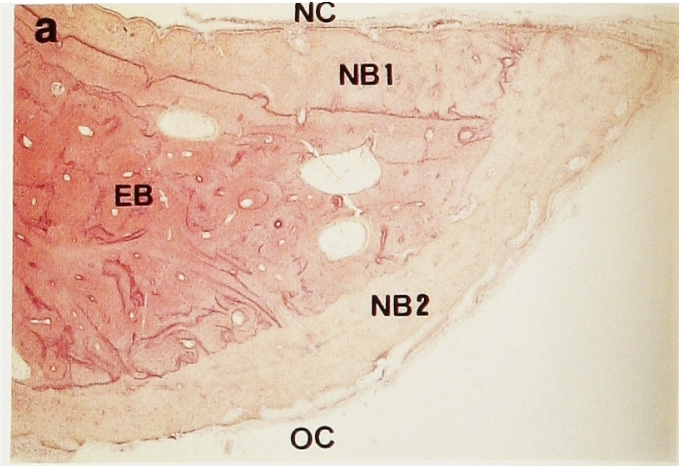

b NC

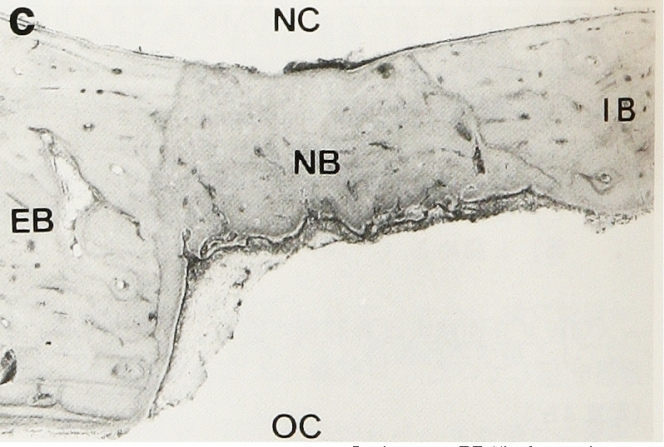

写真 9 粜槽一硬口蓋部の Cole の H-E 染色像 ( 2 分月群)

a：線䧽性結合部：外側断端部の新生骨はまず鼻腔 面に生じ (NB1)，次に切断面に添加 (NB2) し ている $(\times 10)$,

$\mathrm{b}$ ：線維性結合部; 内側断端部の口腔面から外下方 に延びる新生骨 (NB) を認める(×10)

c：骨性結合部; 外側断端部の切断面と内側断端部 の切断面の間で骨性結合 (NB 部)を認める( 10).

X線不透過度の低い梁状の新生骨が相対する断端部に向 かって形成されていた。この新生骨は，1か月群のもの よりもX棌不透過度がやや高く，骨小腔の形態と大きさ b揄ってきていた（写真 $6 \mathbf{b})$.

3. Cole の H-E 染色標本の所見

1) 硬口蓋路片 

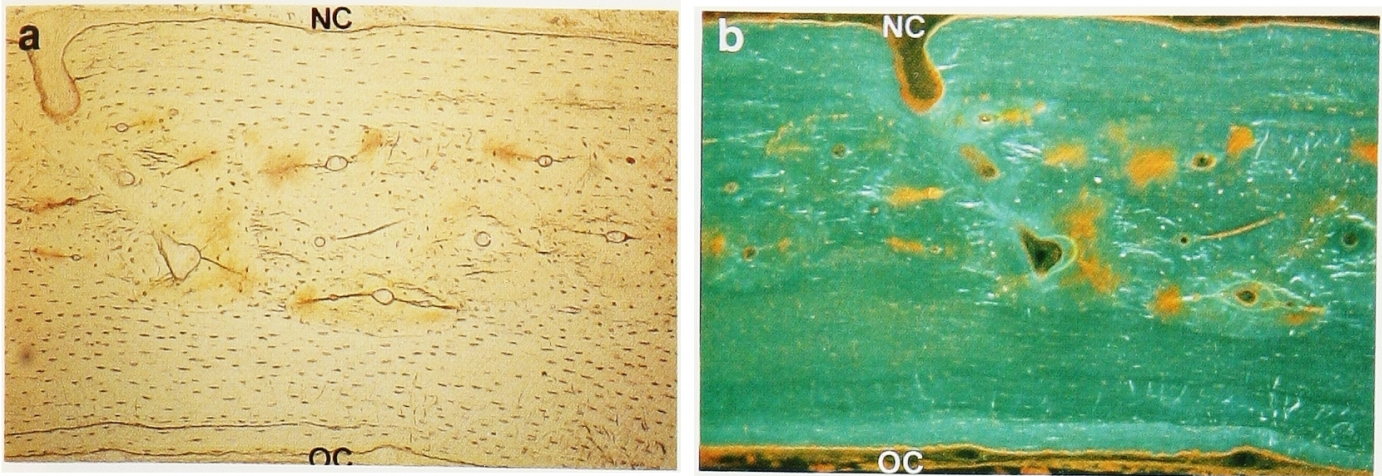

写真 10 硬口蓋骨片の Villanueva bone stain 像（対照群）

a : 類骨を示す赤紫色の部分はほとんど認められない（普通光， $\times 25$ ).

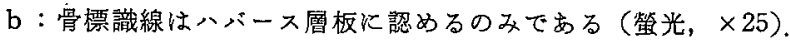
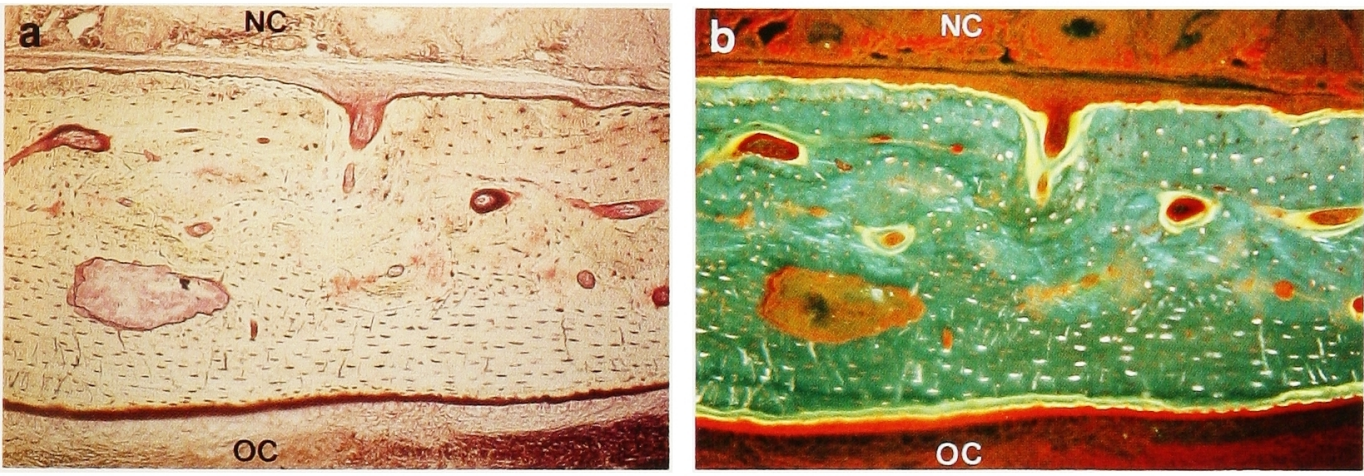

写真 11 硬口蓋骨片の Villanueva bone stain 像 ( 1 か月群)

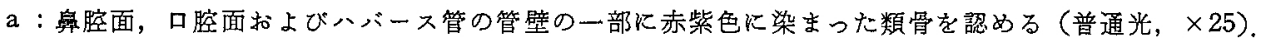

b：赤色の類骨が認められ，これに接した骨表面と骨内に 1 ないし 2 重の骨標識線が観察される(螢光，×25）。

対照群の硬口蓋部は，CMR の所見と同様に 3 層構造 を呈していた，鼻腔面と口腔面は平滑で，ハゥシップ窩 は認められず，類骨層もほとんど観察できなかった（写 直 $7 \mathbf{a}$ ).

1か月群に扣いて，㝴空側基礎層板は消失しており， ハパース層板と介在層板が鼻膑粘膜直下に諰められた。 その表面は凹凸不整でハウシップ窩を認めるものが多か った，口盐側基礎層板は層状の構造が不明瞭となってい るむのの，表面には類骨層が存在し，立方形の骨芽細胞 を伴っていた（写真 $7 \mathbf{b ） . ~}$

2 か月群でも，鼻腔面に破骨細胞を有する多数の八ウ シップ窩が存在し，舅腔側基礎層板のみならず，ハバー ス層板や介在層板，さらに口衉側基礎層板に至る吸収を 琹めた，口腔側では，不規則に配列する骨小腔を含む梁 状の骨形成が著明で，口腔面は立方形の骨芽細胞を伴っ た類骨層で被われていた（写真 7c)．しかし，なかには
骨吸収や形成のほとんどみられないものる観察された。

2) 歯旉一硬口蓋部

1 か月群では線維性の結合が多く，外側断端部の切断 面は山以不整であったが，その鼻腔側には内上方に伸び る新生骨の添加が観察された。 またハバース管あるい はフォルクマン管の一部に管腔の払大を認めた（写直 8a).内側断端部では，新生骨はほとんど認められなか った (写真 $8 \mathbf{b}$ ).

骨性結合を認めるものでは，外側断端部の鼻膑面と内 側断端部の口腔面とをとザイク状の構造を呈する線維骨 が連絡して扣り，その口腔面には，骨芽細胞を伴った類 骨が著明に諗められた（写真 $8 \mathbf{c}$ ）。

2 か月群の外側断端部では鼻腔面，切断面およびロ腔 面に新生骨を認めた。ここでは，まず鼻腔面から始ま り，次に切断面を中心に源加されていく2 相性の形成が 行われていた（写真 $9 \mathbf{a}$ )。一方内側断端部の新生骨は， 

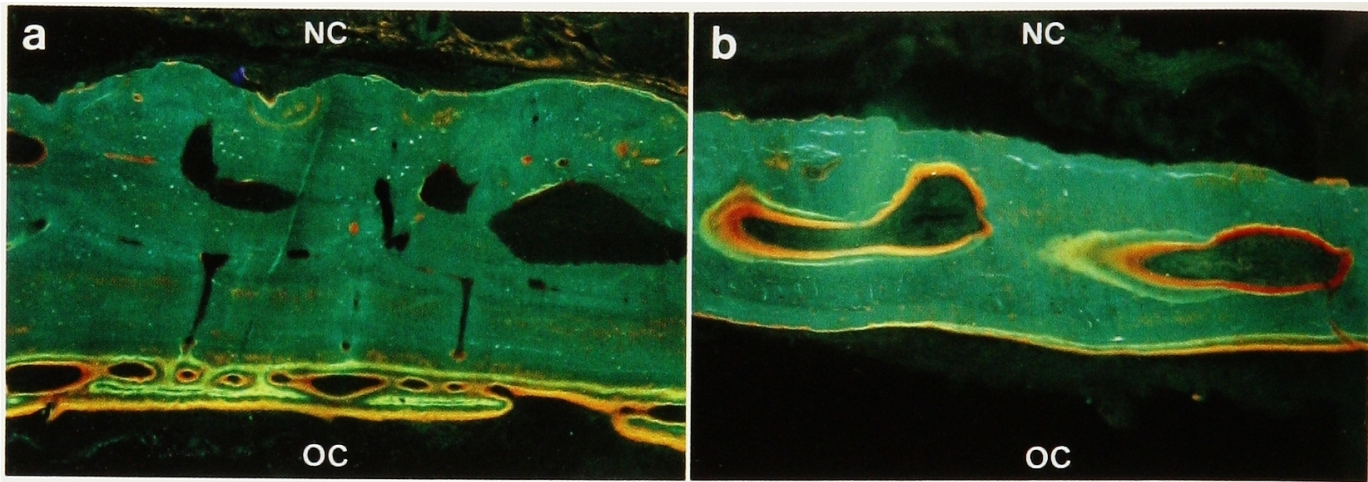

写直 12 硬口蓋骨片の Villanueva bone stain 像（ 2 か月群）

a：口腔側に骨標識像を認める(螢光， $\times 16$ ).

b・フォルクマン管の周囲と口腔側に 2 重骨標識像を認める(螢光, $\times 25)$.
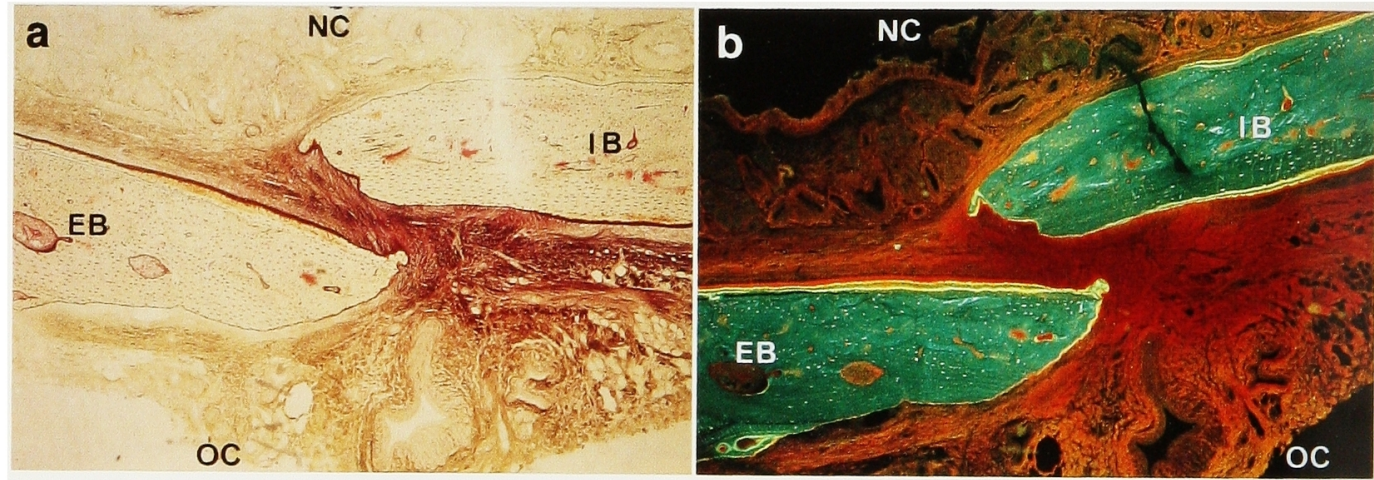

写直 13 遒槽一硬口蓋部のVillanueva bone stain 像 ( 1 か月群)

a ：外側断端部の楀腔面と切断面に類骨を認める。内側断端部では口腔面と切断面に認められる。な和 菌槽一硬口蓋部直下に大口蓋神経血管束が観察される(普通光， $\times 10 ）$.

b : 類骨の付近に 1 ないし 2 重の骨標識線が明膫に認められる。两断端の鼻腔側に骨標識された新生骨 を認める(螢光, $\times 10$ ).

口腔面から外側断端部に向かって添加を示すものが増光 ていた（写真 $9 \mathbf{b}$ ).

また骨性結合を想めるところる多くなり，主に内外側 の切断面からの新生骨によって連結していた，その新生 骨に含まれる骨小腔は層状酒䣦する傾向を示し，口腔 面では類骨括よび骨芽細胞が認められた（写直 9c).

\section{Villanueva bone stain 標本の所見}

\section{1）硬口蓋骨片}

対照群の普通光による钼察では，嵗䐋側と口腔側に層 状の骨を認め，その間には種々の石灰化を示すハバース 層板と介在層板が認められた，類骨に相当する赤紫色の 部分やハウシップ裔はほとんどみられなかった（写直 10 a).

対照群の螢光像の観察では，普通光で薄茶色を呈した
低石灰化部分が橙色に変化する一方, 石灰化の高い部分 は青緑色に観察された．OTCで標識された黄色の線は ハバース檿板に認めるのみであった（写直 $10 \mathbf{b ） . ~}$

1か月群の普通光による観察では，口腔面，鼻腔面お よびハバース管の管壁の一部に類骨が認められ，層板骨 のところどころに石灰化の低い部分が観察された，回聜 側の基礎層板は增状の構造を旺していたが，鼻腔側では 不明瞭となっていたまた払大したフォルクマン管の管 壁にはハウシップ窩が認められ，破骨細胞を含んでいた (写直 11 a).

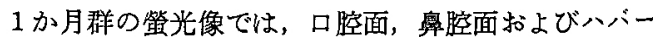
ス管に赤色の類骨層が観察され，これに接した骨表面と 骨内に，OTC の標識像が認められた。特に口腔側では 厚い類骨と 2 重の骨標識線が明瞭であった（写真 $11 \mathbf{b ) . ~}$ 

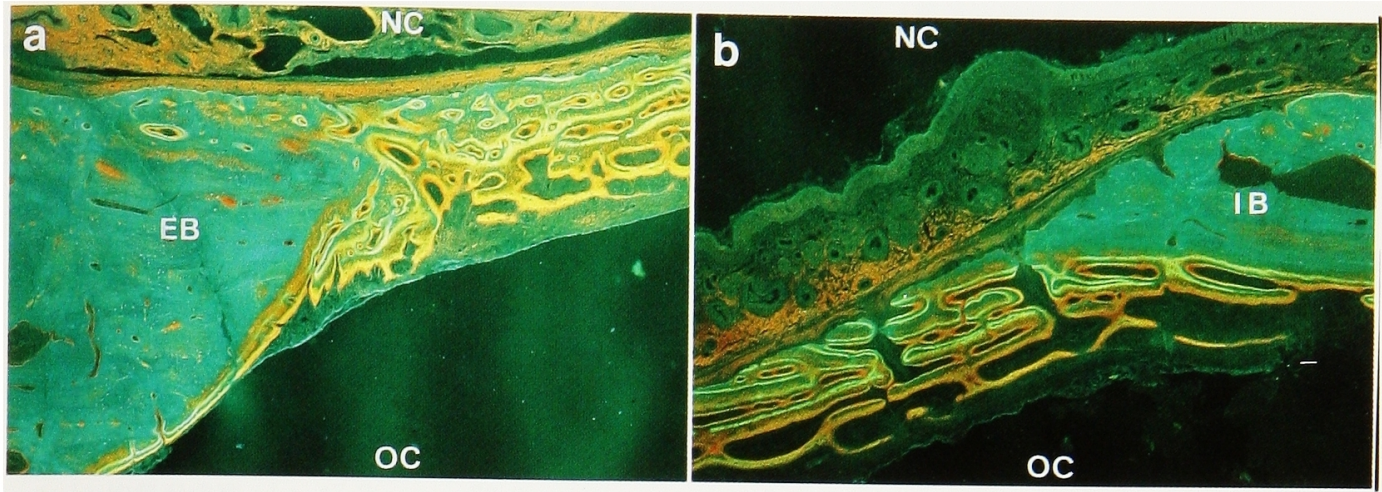

写真 14 歯槽一硬口蓝部の Villanueva bone stain 像 ( 2 か用群)

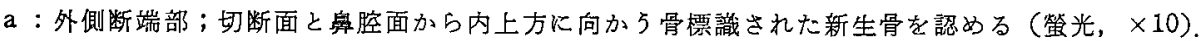

b : 内側断端部；口腔面から外下方に向かって延びる骨標識された新生骨を認める(炳光， $\times 10 ）$.

表 2 新生骨面䅪

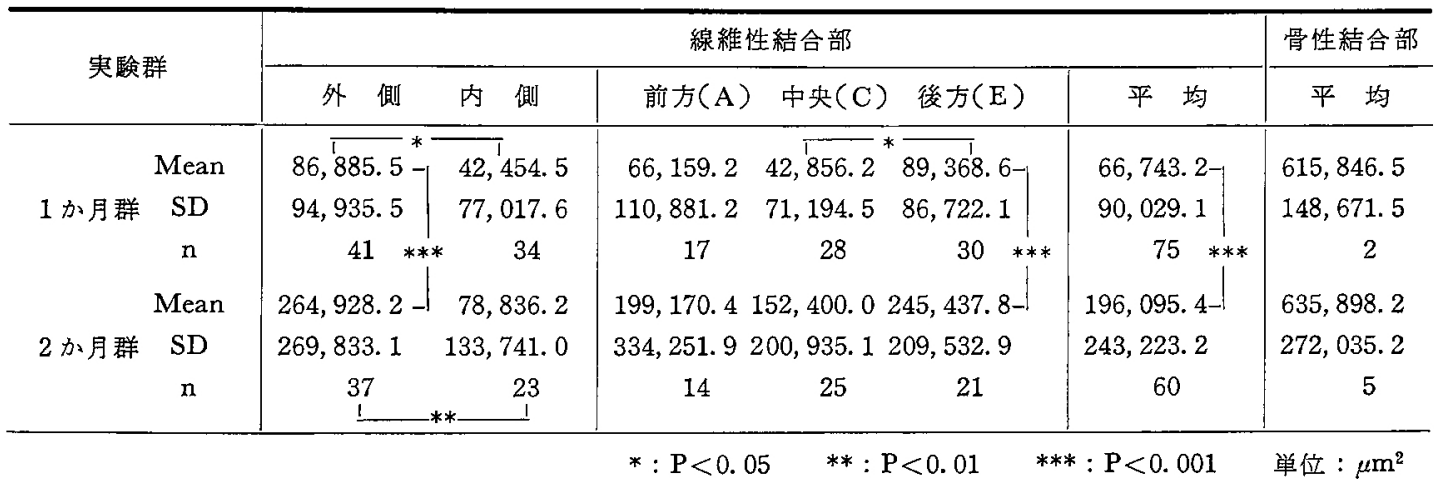

$2 か$ 月群の普通光の所見では，口腔面，鼻腔面および 介在層板の一部に低石灰化部を認めた。類骨はフォルク マン管の管壁に認められ，骨芽細胞が配列していた。こ こでは基礎層板とハバース罩板が不明瞭であった。

2 か月群の䖝光像では，口腔面に拈ける新生骨の添加 を認めるものや（写真 12a）ほとんどが新生骨によっ て置換されたるのがみられた。またハバース管やフォル クマン管の拡大を認め，管壁の類骨や層板内の骨標識線 も観察された，奥腔面は凹凹不整で，骨吸収を示唆する ものが多かった（写真 $12 \mathbf{a}, \mathbf{b}$ ).

2) 歯槽一硬口蓋部

1 か月群の普通光による外側断端部の観察では，切断 面と净腔面に類骨が認められ，特に鼾腔面で明膫であっ た。内側は口腔面と切断面の一部に類骨を認めた（写直 $13 \mathbf{a}$ ).

1 か月群の螢光像では，外側断端部の赤色の類骨に接 して骨標識線がみられた。これは特に鼻腔側において明 瞭に観察され，切断面に移行するとこるは上方に向かっ
てわずかに突出していた，内側断端部は同様に類骨の内 側湦標識像が認められた（写真 $13 \mathbf{b})$.

2 か月群の普通光下の外側断端部は，㚬断面を中心に 薄茶色の低石灰化の部分がみられ，類骨も観察された。 内側断端部においては，切断面から口腔面にかけて石兏 化の低い新生骨に相当する部分が認められた。

2 か月群の螢光像では，単純な $1 ， 2$ 本の骨標識線を 示するののほかに，複雑で迷路のよらな所見を呈するす のも多く観察された（写真 $14 \mathbf{a}, \mathbf{b}$ ).

5. 新生骨面積および補正新生骨面積の測定結果

1) 新生骨面積 (表 2)

線維性結合部と骨性結合部に分けて新生骨の骨質の量 を面積として表した。

線維性結合部の粀槽一硬口蓋部 1 断端あたりの新生骨 面積は，2か月群が 1 か月群の約 2.9 倍の值を示した。 また断端部の内外側別でみると，ともに外側で大きく， 1か月群では内側の約 2.0 倍, 2 か月群では約 3.4 倍であ った，次に骨切り部の前後的な部位別によって比較した 
表 3 断端部厚径

\begin{tabular}{|c|c|c|c|c|c|c|c|c|c|c|}
\hline \multirow{2}{*}{\multicolumn{2}{|c|}{ 実験群 }} & \multicolumn{6}{|c|}{ 線維性結合部 } & \multicolumn{3}{|c|}{ 骨性結合部 } \\
\hline & & 外側 & 内㑡 & 前方(A) & 中央 (C) & (後方 $\mathrm{E}$ ) & 平 均 & 外側 & 内側 & 平 均 \\
\hline \multirow{3}{*}{1 出月群 } & Mean & 739.7 & $\sqrt{424.7}$ & 565.8 & 656.0 & 648.2 & $630.4-$ & 1350.0 & 537.5 & 943.8 \\
\hline & $\mathrm{SD}$ & 294.7 & 261.5 & 330.2 & 304.0 & 322.0 & 320.8 & 200.0 & 262.5 & 468.5 \\
\hline & $\mathrm{n}$ & 32 & 17 & 12 & 15 & 22 & $43 *$ & 2 & 2 & 4 \\
\hline \multirow{3}{*}{2 か月群 } & Mean & $930.1-$ & 382.0 & 749.1 & 706.9 & 853.0 & 771.8 & 1096.0 & 596.0 & 846.0 \\
\hline & $\mathrm{SD}$ & 313.8 & 268.4 & 409. 3 & 385.0 & 370.7 & 313.8 & 342.1 & 279.3 & 400.1 \\
\hline & $\mathrm{n}$ & $\begin{array}{c}37 \\
1\end{array}$ & $\begin{array}{r}15 \\
* \quad 1\end{array}$ & 11 & 21 & 20 & 52 & 5 & 5 & 10 \\
\hline
\end{tabular}

表 4 補正新生骨面積

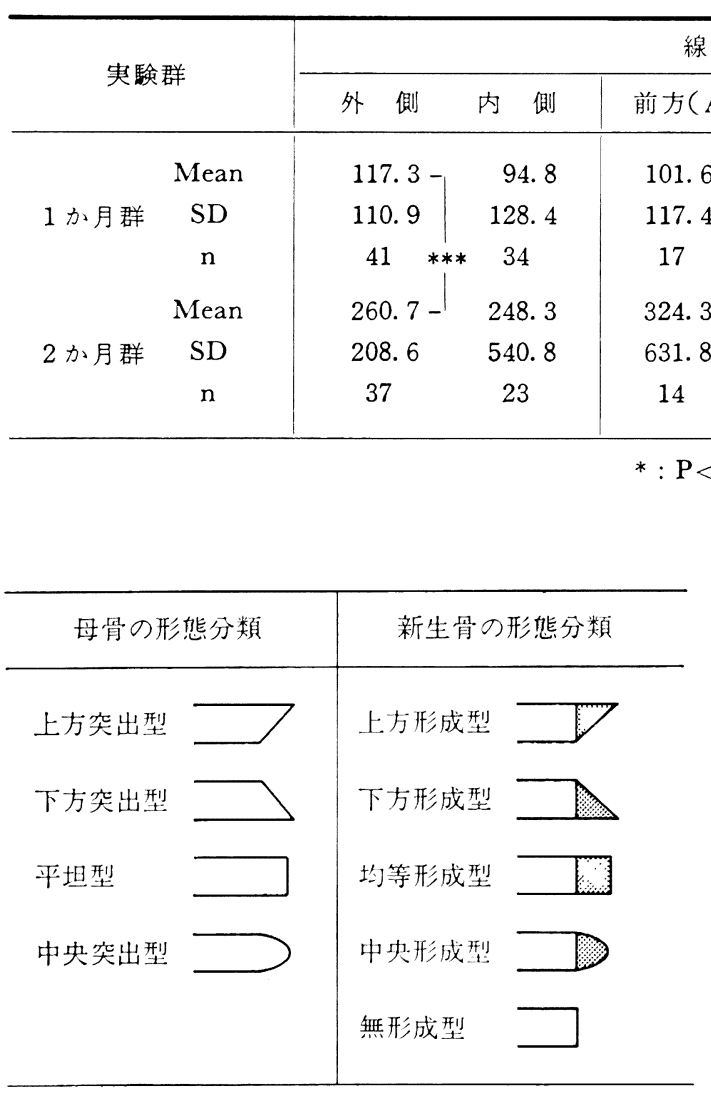

図 7 母:骨と新生骨の形態分類

ところ，両群とも後方（E）が最も大きく，ついで前方 （A），中央（C）の順であった。骨性結合は1 か月群で 2 か所, 2 か月群で 5 か所隹認められ，両群の面積に大 差はなかった。

2) 断端部厚径 (表了)
線維性結合部における断端部厚径の平均は 1 か月群に 比較して 2 か月群のほらがやや大きかった。内外側別て みると，両群とも外側で大きな值を示した，また骨性結 合部においても, 両群の外側で大きな値を示した。

3) 補正新生骨面積 (表 4)

線維性結合部の補正新生骨面積の平均は, 2 か月群で 1 か月群の約 2.4 倍の值を示した。両群とも内外側の間 での大差は認めなかったが，外側について両群を比較す ると, 2 か月群は 1 か月群の約 2.2 倍，内側について 約 2.7 倍であった，前後的な部位別にみると，1 か月群 が後方 (E), 前方 (A), 中央 (C) の順で大きかった のに対し, 2 か月群は前方 (A), 後方 (E), 中央 (C) の順であった，骨性結合部では，2 か月群のほうが 1 か 月群よりもやや大きな值を示した。

4) 補正新生骨面積と断端部形態の関係

骨切り断端部の母骨と新生骨について形態分類を設定 した（図 7).

（1）線維性結合部の母骨および新生骨の形態と補正新 生骨面積の関係（表 5)

母骨の形態は, 外側では1 か月群, 2 か月群とも上方 
表 5 断端部の骨形熊と補正新生骨面䖽の閔係(線維性結合部)

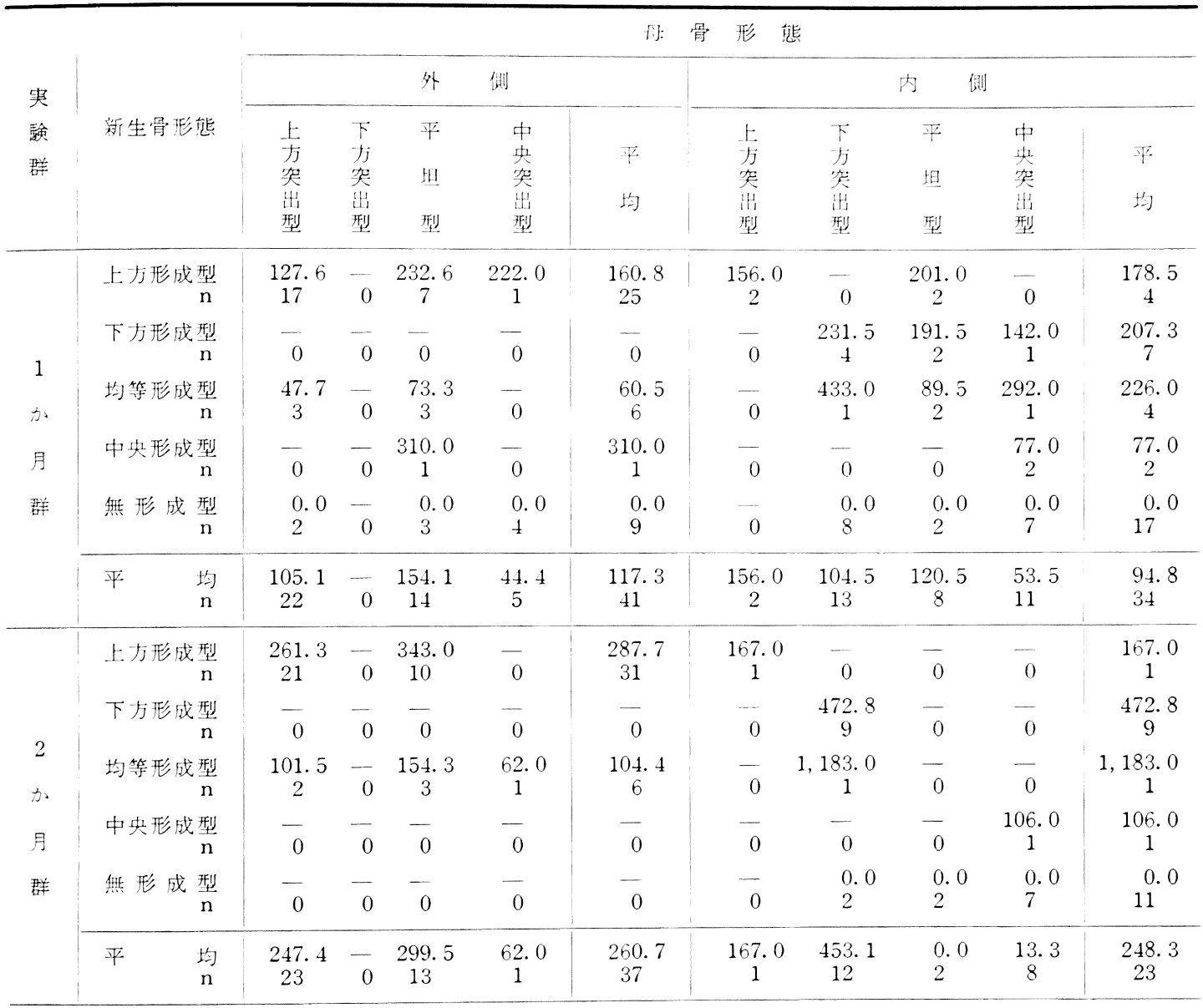

突出型が最も多く，下方突出型は認められなかった。内 側では下方突出型が多かった。これらの補正新生骨面積 の平均は, 外側では平坦型が大きく, 次が上方突出型で あった。

新生骨の形態分類の結果, 両群とも外側ては上方形成 型, 内側では無形成型を除くと下方形成型が多く, 面程 においては外側で上方形成型，内側で下方形成型，均等 形成型が大きな值を示した。

母骨之新生骨の組又合わせは，両群之も外側では上方 突出型十上方形成型, 内側では下方突出型十下方形成型 於多く認められた。

（2）骨性結合部の母骨の形態之補正新生骨面積の関俰 (表 6)

1 か月群は 2 か所とも外側母骨形態が上方突出型, 内 側母骨形態は下方突出型であった。2 か群では，3 通 りの組み合わせがみられた。これらの補正新生骨面積は
表 6 断端部の骨形態之補正新生骨百馧の荓係（骨 性結合部)

\begin{tabular}{|c|c|c|c|}
\hline \multirow{2}{*}{ 実験群 } & \multirow{2}{*}{ 内倒母:骨形態 } & \multicolumn{2}{|c|}{ 外側母:骨形態 } \\
\hline & & 上方突出型 & 平坦型 \\
\hline 1 か月群 & 下方突出型 & $\begin{array}{c}324.0 \\
2\end{array}$ & $\overline{0}$ \\
\hline \multirow{2}{*}{2 名月群 } & 上方突出型 & $\overline{0}$ & $\begin{array}{c}435.0 \\
1\end{array}$ \\
\hline & 下方突出型 & $\begin{array}{c}351.5 \\
2\end{array}$ & $\begin{array}{c}388.0 \\
2\end{array}$ \\
\hline
\end{tabular}

両群とも, 楾維性絬合部の 2 力月碓にお汁万内外側の值 の和よりも小さかった。 
表 7 類骨層石灰化速度

\begin{tabular}{|c|c|c|c|c|c|c|c|}
\hline \multirow{2}{*}{\multicolumn{2}{|c|}{ 実験群 }} & \multicolumn{5}{|c|}{ 線稚性結合部 } & 骨性結合咅 \\
\hline & & 外側 & 内側 & 前方 (B) & 後方 (D) & 平均 & 平均 \\
\hline \multirow{3}{*}{1 か月群 } & Mean & 2. 70 & 1. 72 & 1.95 & 2. 43 & 2. 20 & - \\
\hline & SD & 2. 02 & 1.76 & 1.76 & 2.09 & 1.95 & - \\
\hline & $\mathrm{n}$ & 32 & 34 & 32 & 34 & 66 & 0 \\
\hline \multirow{3}{*}{2 少月群 } & Mean & 2.00 & 1.34 & 1.85 & 1.50 & 1.67 & 4. 23 \\
\hline & SD & 1. 44 & 1.60 & 1. 78 & 1. 30 & 1.56 & 1.59 \\
\hline & $\mathrm{n}$ & 20 & 20 & 19 & 21 & 40 & 6 \\
\hline
\end{tabular}

\section{6. 類骨層石灰化速度の測定結果（表 7 ）}

線維性結合部门拈计る類骨層石灰化速度の平均は， 2 か月群に比べて1か月群のほらがやや大きく, 内外側別 では両群とも外側において大きかった。骨性結合部て は，1か月群で測定可能な標本が得られなかった２か 月群 6 か所の平均は, 線維性結合部の值に比べてかなり 大きな値を示した。

\section{考察}

日常生活にお汁る身体活動の制限は，高路者の場合， 特に精神活動に対して大きな影響を及ぼすことが判明し ており ${ }^{13)}$ ，その中で咀嚼機能の確保が重要な条件となる ことも示唆されている ${ }^{14}$ ，義蒾に上る咀啋機能の回復に おいて，歯慒堤の萎䈹が問題であり，これに対する外科 的手段としては，近年，人工材料や歯科インプラントの 臨床応用が盛んになりつつあるが，上買の場合，臼歯部 の直上に上頸洞が存在することなどから多くの制䄪を抱

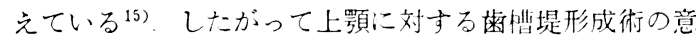
義は，高く評価されてよいものと考える。

上罘流対する歯槽堤形成術として, 口腔前庭形成術 ${ }^{16)}$ ， 上腼結節形成術 $\left.{ }^{17}, 18\right)$, 頓骨下稜圧迫術 ${ }^{199}$ 掞よび硬口蓋圧 迫術（口蓋深形成術）が考案，応用されてきた。著者は その中で，臨床的意義か大きいと思われるにもかかわら 寸゙治瘾経過が解明されていない口蓋深形成術について， 骨の形態計測の手法を取り入れながら，多角的かつ動的 研究を試みた。

\section{1. 口蓋における手術創の治虑について}

口蓋における手術創の治疮経過に関する報告は，口蓋 裂に対する口蓋形成手術を想定した研究が注とんどであ る 20 30)。これらの結果をまとめると，次のようになる。

1) 大口蓋動脈切断に上る口蓋発育に対する影響は少な い、ただし大きな影響を及ぼすとの報告もある23)。2 ) 口蓋粘膜升を制離しても骨膜を保存した場合には，口蓋
の発青抑制は生じない，3）口蓋粘膜骨膜が除去された 場合は発育抑制が生ずる。4）骨は一部除去されても再 生し，口蓋の発育抑制は生じないか，もしくは生してても 軽度である。たたし正中口蓋縫合部を除去した場合，側 方発育に影響を及ぼす。） 口蓋の骨およびそれに付着 する軟組織の一部を除去し，側方の粘膜骨膜弁で被覆し た場合, 発青抑制が生ずる。

以上の結果から，本研究における骨切りは歯㡟部内側 と正中口蓋縫合部になされているため, 骨の治痏不全や 変形を惹起する臨念が持たれる. しかし上述の研究が, すべて発育期の動物を対象としているのに対し，本研究 では成犬を用いたといら点で異なっている。また本手術 の骨の削除量がきわめて少なく， 口蓋の粘膜骨膜の不足 が汪とんどないこと，さらに大口蓋動脈を保存している ことなどから，術後の口蓋の変形や縮小をきたすことな く，治痪を期待できるものと思われた。

\section{2. 研究方法および成績について}

1) 軟X線写真の钼察について

軟 $\mathrm{X}$ 缐写真による口蓋の研究:よ, 高橋ら ${ }^{311}$ がラットの 正中口蓋縫合の拉大㬰験に用いて，拉大量の測定に応用 している。著者は，まず摘出した上顎の軟X線写真を撮 影して，骨性結合の概要を観察した。

今回の実験では，骨切门部に全く骨珄結合を認めない ものから，ほぼ全周にわたって認められるものまでさま ざまであった。しかし遊離した硬口蓋骨片の固定された 位置により，骨性結合をきたしているかのように誤って 観察される場合がある。このため，本研究では 2 通りの 撮影条件を設定して観察を行った。

その結果，骨切りを行った歯槽一硬口蓋部における骨 性結合部は，2 か月群においても $35 \%$ と少ない割合であ った，したがって本研究で設定した実験期間は，線維性 結合から骨性結合に移行する時期に相当し，この期間の 硬口蓋骨片の確実な固定の成否が予後に大きな影響を与 えるものと考兄られた。 


\section{2) CMR の観察について}

CMR を用いた靧骨の骨切り術後の治瘾に関する報告 のほとんどが下顎に対するものであり，上䫍に応用され た研究

本研究の所見では, 1 か月群の硬口蓋骨片の鼻腔側に 骨吸収がみられ，2か月群では鼻腔側の骨吸収が継続す るとともに，口腔側の活発な骨新生像を示すものが観察 されたままた歯慒一硬口蓋部は，後述するCole の H-E 染色像之類似していたが, 石灰化の観察に関して，CMR はより有用な方法と思われた。

3) 非脱灰研嚰標本の観察について

骨の組織学的動態の観察には, 類骨と骨の判別や骨梆 識が可能で，かつ骨芽細胞や破骨紐胞などの細胞成分も 観察できる薄い非脱灭標本が必要である。本研究では, 本間ら ${ }^{10)}$ の方法と今野ら ${ }^{33)}$ の方法を参考にして, 非脱灰 研磨標本を作製し, 組織学的観察と骨形態計測を行っ た.

Cole の H-E 染色標本の組織学的所見では，1 か月群 の硬口蓋骨片は番腔側から破骨細胞に上る吸収か始ま り，2か月群になると吸収が促進される反面，その口腔 側では骨芽細胞と類骨を伴ら活発な骨形成が生じてい た， 口蓋側は，粘膜骨膜を剝離したにもかかわらず吸収 がなく，むしろ侵襲の少ない鼻腔側に吸収が起こるとい う結果は興味が持たれる。これは硬口蓋骨片を上力に圧 迫，移動したことによって重腔底粘膜の祭張が高めら れ，血流障害が生じたための変化，または舅腔と口腔の 粘膜もしくは粘膜下組織の差によるものであると考兄て いる。また，2 か月群の硬口蓋骨片口腔側の骨新生は， 術後 1 か月で固定を除去したことにより，圧迫が解除さ れて大口蓋動脈を中心とした血流が増えたことに起因す るものであろう.

骨切り断端部の骨形成の観察では，外側断端部は鼻腔 側から，内側断端部は口腔側からの新生骨を認め, これ は両側断端の最短距離に生じた変化である。また 2 か月 群の外側断端部では, 新生骨が 2 層に分かれて添加する 所見を認めた。これは，まず術後 1 か月間は固定のた め, 骨の下方もしくは内方への涯加が抑制されているの に対し，上方へは障害となるものがなく，さらに相対す る内側骨片に最も近い位置にあることにより鼻腔面から の内上方への骨形成が生じ，次に固定除去後の圧の解除 によって，内方に形成方向が変化したための結果と考兄 られる。

1957年 Milch ら ${ }^{34)}$ は，骨標識物質としてテトラサイ クリン系抗生物質（以下 TC と略す）が骨に沈着するこ とを報告した，TC は新た汇石灰化しつつあるアパタイ 卜に取り込まれてキレート結合し ${ }^{35)}$ ，紫外線を当てると この部分が黄色の螢光を発する。その他の骨標識物質で は，カルセイン，アリザリンレッドなども使用されてい るが，本実験では TC のらち OTC を選び，2回骨標
識を行った。

Villanueva bone stain 標本を普通光で観察すると, 1か月群の硬口蓋骨片では口腔面, 鼻腔面およびハバー ス管の管壁の一部に類骨を認めた. 2 か月群においては, 口腔側で著明な類骨や低石灰化部がみられるものから吸 収, 添加のないものまで，さまざまな所見がみられた。 これらの䖝光像を観察すると, 対照群は骨標識像が注と んど認められ寸゙，1か月群では，類骨に接した骨標識像 を認め, 特に口腔側において明瞭であった。 2 か月群で は多彩な骨標識像が得られた。

歯槽一硬口蓋部の観察では，1か月群の外側断端部は 切断面よりも奥腔面に，内側で口腔面に骨標識像を認 め, 2 か月群の所見では, 切断面からの新生骨にも標識 像がみられた。これらの標識像のほとんどは類骨に接す るか,もしくは近い部位に認められ，また普通光および 前述の Cole の H-E 染色像に掉いて立方形の骨芽細胞 の配列がみられたことから，骨形成が活発に営まれてい ることがわかった。

4) 骨形態計測について

骨形態計測は，骨のリモデリングの動態を解明するた めに, 骨組織を定量的に計測するもので，本邦では第 1 回のワークショップが1979年に開催された。この手法は 代謝性骨疾患の診断や病態の解明, 薬剤の効果判定など に使われてきたが，近年になって口腔領域でも骨形態計

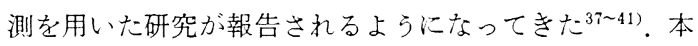
研究では, この組織学的形態計測法を応用し, 骨切り部 の新生骨の動驡を観察した。

まず新生骨面積の钼察において, 歯槽一硬口蓋部の楾 維性結合では，2 か月群が1か月群の 3 倍に近い大きな 值を示し，骨が形成される割合は一定でないことが示唆 された。 また断端の内外側別て観察したところ, 外側の 面積が有意に大きかった。しかし内外側で断端の厚さが 西きらかに異なっていたため, 補正新生骨面積を求めて 比較を行った。 その結果 2 か月群は 1 か月群の 2 倍以上 の值を示したが，内外側では大差がみられなかった，し かし内側の值のばらつきが大きかったため, 骨の形成量 が断端の厚さに比例して内外側の骨形成能に差がないと はいいがたい，このばらつきの主因として，手術時に上 方に移動させた硬口蓋骨片を一定の位置に固定できなか ったことを考光ている。

骨性結合部は 1 か月群で 2 か所, 2 か月群で 5 か所に 認められ，これは全観察部位の $5 \%$ に相当した。軟X線 写真からの骨性結合の評価と比較すると，かなり低い割 合であって軟X線写真の所見では 2 条件で観察したにも かかわらず，偽性の骨性結合が多いことがわかった。補 正新生骨面積は, 2 か月群のほらが1か月群よりもやや 大きいものの 2 倍には至らず，骨性結合をきたすと骨の 量の増加よりも, 石灰化をはじめとする骨の成熟が起こ るものと推察された。 
次に, Cole の H-E 染色像から骨切り断端部の母骨之 新生骨の形態を分類し, 補正新生骨面積を骨形成能の指 標として，形態別に検討を行った。その結果，両群とも 母骨の形態は外側断端部で上方突出型，内側断端におい ては下方突出型を示すものが多かった。また新生骨形態 としては, 外側:上方形成型, 内側は無形成型を除くと 下方形成型が多く，その面積も比較的大きかった。母骨 と新生骨の組み合わせでみると，外側は上方突出型十上 方形成型，内側は下方突出型十下方形成型が多く認めら れた。

この結果と組織学的所見から，歯槽弓と平行な骨切り そ硬口蓋に施した場合，外側断端部の母骨は，口腔側て 吸收を受けて上方突出型を呈し，新生骨はその切断面上 方もしくは鼻腔面から内上方に向かって形成される傾向 をもつことが判明した。また内側断端部は，主に鼻腔面 で吸収を受けて下方突出型を示すものが多く，新生骨は その切断面下方もしくは口腔面から外下方に向かって添 加することがわかった。すなわち外側断端部の鼻腔側と 内側断端部の口腔側が骨吸収の少ない安定した部位であ り，この部分が可及的に近接するように遊離した硬口蓋 骨片を配置させることが治癒を促進するらえで重要と思 われた。そのためには，歯慒己と平行な骨切りの際，意 四的に外側断端部が上方突出型もしくは平坦型，内側断 端部が下方突出型になるような形態を作成しておけば， 骨形成がより速やかに行われるものと推測された。

また骨切りを行う部位は，なるべく歯憎頂寄りに設交 し，口蓋の表面積の扗大を計るべきであるが，この際上 顎洞人の穿孔に注意する必要がある。すなわち上村 ${ }^{41}$ に よると高齢者の中等度から強度に吸収した歯槽堤（口蓋 面から歯槽頂の高さか $10 \mathrm{~mm}$ 末満) は上䫇洞と近接し， 26例全例が歯槽頂より煩側に洞底線が位置していたが， 洞底部は口蓋側にも及んでおり，さらにX線写真上，上 嚬洞下縁が鼻腔底よりも下位にあるものが大部分であっ た。したがって骨切り線の位置設定に際しては，前額断 の断層X線写真や CT scan による検討が必要であると 思われる。

堀と高橋ら ${ }^{42}$ は，ビーグル犬を用いて OTC とカルセ インの 2 回骨標識を行い, 骨梁の標識像を 4 型に分類し ている。本実験でも類骨を伴った 2 重骨標識が多く認め られたが，観察の対象が新生骨であるため多彩な像を呈 した，類骨層石灰化速度の概念を骨の治瘜に応用し定着 させるためには，まず新生骨の標識パターンを詳細に観 察して独自の分類を作る必要があると考えている.

南部 ${ }^{40}$ は家兔下顎骨にヒドロキシアバタイトを埋入 し，骨形成を類骨層石灰化速度によって観察しており， 術後 2 週以後, 速度が鈍化してくると述べている。本実 験の結果では，2 か月で速度の有意差はなく，線維性結 合部の類骨層石灰化速度は画群とも外側断端部において 大きい傾向を示した。なお楾維性結合部の補正新生骨面
積においては内外側断端部の值に大きな差を認められな かったことを考えると，この結果は矛盾しているように も思えるが，外側断端部では切断面の上方部を中心に骨 の泒加が起こっているため，ここにおける比較的間隔の 広い 2 重骨標識像のデータが多く取り込まれたことによ るものと解积される。また骨性結合部の類骨層石灰化速 度が大きな值であったにもかかわらず，補正新生骨面積 は線維性結合部の内外側の平均の和より小さかった。 れは骨性結合によって骨の添加方向が下方のみに規制さ れ，涯加される範囲が狭いことに起因寸るものと考えら れた。

\section{結論}

雑種成犬 25 頭に口蓋深形成術を施し, 術後 1 か月もし くは2か月で上顎部を摘出した。そして軟X線写真, CMR, 非脱灭研磨摽本の所見および骨形態計測の結果 から, 本手術施行後の歯槽一硬口蓋部に拈ける治瘉過程 を検討し，以下の結論を得た。

1. 術後 2 か月は 1 か月よりも骨の形成が活発であっ たが，また骨性結合に乏しく，修復の途中であることが 示された。

2. 口蓋の骨切りによって遊離した硬口蓋骨片は, 鼻 腔面で骨吸収，口腔面で骨形成が生じていた。

3. 骨切り両断端は，最短距離のところで互いに引き 合らかのように，外側からは内上方，内側からは外下方 に向かって骨が形成されていた。

4. 断端部の新生骨面積は外側のほうが大きかったが， 補正新生骨面積では，内外側で差を認めなかった。

5. 断端部の母骨を 4 型，新生骨を 5 型に分類した。 外側の母骨は上方突出型を呈するものが多く，内側では 下方突出型が多かった。外側からの新生骨は上方形成型 が多く，内側ては無形成型を除くと下方形成型が多かっ た。

6. 類骨層石灰化速度は内侧: 比べて外側のほうが大 きい値を示した。

以上より，吉澤一高橋の口蓋深形成術施行後の骨切り 断端部にお汁る母骨之新生骨の形態之組織学的特徵, な らびに新生骨の形成量，形成方向および形成速度が解明 された。

稿を終えるにあたり，こ指導とご坋閲を晹った吉澤信 夫教授に深甚なる感谢の意を表します。また，ご援助を いたたいた梀科口腔外科学教室の諸兄に感謝いたしま 立。

本㻆文の要旨は，第34回日本口腔外科学会総会（1989 年10月，郡山）に执いて発表した。

な扮, 本研究の一部は, 昭和60年度文部省科学研究费 補助金（奖励研究A，課题番号60771691）ならびに平成 
2 年度文部省科学研究費補助金（奖励研究 $\mathrm{A}$, 課题番号 02771480)によって行われた。

\section{引用 文 献}

1) Wassmund, M.: Über chirurgische Formgestaltung des atrophischen Kiefers zum Zwecke prothetischer Versorgung. Vrtl Jhrschr Zahnhk 47: 305-319 1931.

2) Charest, A. and Goodyer, V.: Palatal osteotomy; a simple approach to maxillary alveolar atrophy. J Oral Surg 34: 442-444 1976.

3) Leonald, M. and Howe, G.L.: Palatal vault osteotomy. OS OM OP 46: 344-348 1978.

4) Steinhäuser, E.W.: Methoden zur operativen Verbesserung der Gaumenwölbung. Zahnärztl Prax 29: 50-54 1978.

5) Tiner, B.D., Aragon, S.B., et al.: Modification of the palatal vault osteotomy. J Oral Maxillofac Surg 44: 489-491 1986.

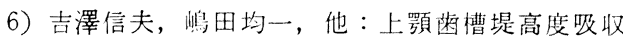
例に対する硬口蓋圧迫街について。 日外誌 27: 1602-1608 1981.

7) 楠本健司, 藤本久夫, 他：上顎㴹槽堤高度吸収 例に対して施行した硬口蓝圧迫街の1例（抄）。 日口外誌 29: 11841983.

8) 北山誠二, 織田元, 他：著しい上顎芼槽堤吸 収に応用される硬口蓋圧迫術の一工夫。日口外 誌 33: 791-796 1987.

9）柴田整，江良謙次，他：口蓋隆起々義㴹性線 維腫の合併症例に対して行った硬口蓋圧迫術招 よび口腔前庭形成術について（抄），日口外誌 35: 30461989.

10）本間哲夫，若松英吉：非脱灰研磨染色標本作製 法。高橋英明編; 骨形態計測ハンドブック、第 1 版, 西村書店, 新潟, 1983, 34-44頁.

11) Cole, E.C.: Studies on hematoxylin stains. Stain Techol 18: 125-142 1943.

12) Villanueva, A.R.: A bone for osteoid seams in fresh, unembedded mineralized bone. Stain Techol 49: 1-8 1974.

13）生地 新：高齢化社会にお打る地域住民の心身 機能と保健行動に関する研究。日本公衛誌 34 : 239-250 1987.

14) 平井敏博, 田中収, 他: 高路者の咀礵機能々 精神活動。口科誌 37：562-570 1988.

15）森川雅之, 西嶋克巳, 他・インプラントにより 知覚異常ならびに上顎洞炎を生じた 1 例。日口 腔インプラント誌 3：235-240 1990.

16) Wallenius, K.: Ridge extension; A modified operative technic. J Oral Surg Anesth 21: 54-59 1963.

17) Čelešnik, F.: Die Tuberplastik. Österr Z Stomat 51: 584-587 1954.

18) Obwegeser, H.L.. Surgical preparation of the maxilla for prosthesis. J Oral Surg Anesth 22: 127-134 1964.

19) MacIntosh, R.B. and Obwegeser, H.L.: Preprosthetic surgery; A scheme for its effective employment. J Oral Surg 25: 397-413 1967.

20) Herfert, O.: Fundamental investigations into problems related to cleft palate surgery. $\mathrm{Br}$ J Plast Surg 11: 97-105 1958.

21) Sarnat, B.G.: Palatal and facial growth in Macaca rhesus monkeys with surgically produced palatal clefts. Plast Reconstr Surg 22: 29-41 1958 .

22) Kremenak, C.R., Huffman, W.C., et al.: Growth of maxillae in the dogs after palatal surgery I. Cleft Palate J 4: 6-17 1967.

23) 新橋武, 石井昌博, 他: 口蓋江対する侵䪭が 顔面骨に及活吉影吿についての硬組織学的研究 (第正報)。形成外科 23：459-461 1980 .

24）角谷徳芳：幼若ラット口蓋への外科的侵䋿によ る影響。昭医誌 41：481-492 1981.

25）伝庄信也，小松世潮，他：幼犬の口蓋粘膜切除 による上顎骨発育の変化汇関交る実駼的研究。 札幌医誌 50：499-512 1981 .

26）伝庄信也：幼若ラットの口蓋に执计る各種手術 創の治療過程に関する組織学的ならでに走査電 子頙假鏡的研究。札幌医誌 51：243-260 1982.

27）在藤兼重：幼若ラット口蓋への外科的侵襲の影 艟についての実験的研究。昭医誌 43: 75-89 1983.

28）森谷研介：口蓋裂修復街に関方実験的研究。 日耳奋 69：1738-1749 1966 .

29）永井直人：正中口蓋䋖合欠如が顎発育に及活方 影瑟に関する実験的研究, 第 1 報; ラット正中 口蓋程合切除後の組織学的钼察。日口蓋誌 12 : 85-102 1987.

30）永井直人：正中口蓋释合欠如か顎発育に及ほす 影響に関方る実験的研究，第 2 報; ラット正中 口蓋縫合切除後の計測学的钼察。日口蓋誌 12 : 103-116 1987.

31）高橋 治, 清水典佳, 他：ラット正中口蓋䋖合 扗大実験に打ける锶察部位, 钼察方法に関する 一考案。 日大口腔科学 15：473-481 1989.

32）木津喜考：上顎骨の夷験的急速侧方执大に上る 骨組織のラベリング法とマイクロラジオグラフ イによる研究。茀学 66: 686-722 1979.

33）今野沿应，高橋柴明：非脱灰研糜標本の作成法。 高橋栄明編; 骨形態計測ハンドブック第 1 版, 西村書店, 新潟, 1983, 28-33頁.

34) Milch, R.A., Roll, D.P., et al.: Bone localisation of the tetracyclines. J Nat Cancer Inst 19: 87-93 1957.

35) Ibsen, J.L. and Urist, M.R.: The biochemistry and the physiology of the tetracycline. Clin Orthop 32: 143-169 1964.

36) 筥塚品, 米良和彦, 他: bone matrix gelatin 
の骨誘導に関方る実験的研究, 骨形態計測に上 る組織学的研究, 第 2 報 (抄): 口科誌 33 : 774-775 1984.

37）遠藤 実：卵䉾摘出後の骨代謝異常に関する研 究, 脛骨の成長と拔㐘創の修復過程について。 岩医大菌誌 11：175-194 1986.

38) 近藤寿郎, 李 健柱, 他: 単骨性線維性骨異形 成症に打ける骨組織の性状について。外誌 33: 90-96 1987.

39）藤原道夫：日本人有遒下顎骨の内部構造に関す る研究。菌科学報 89: 81-104 1988.
40）南部淑文：ヒドロキシアパタイトの顎骨欠損部 への応用に関する実験的研究, 特にアパタイト 界面部の血管像と骨形成について。 日外誌 36: 15-24 1990.

41) 上村次郎：無㳡顎と有谏顎の上顎骨の形態学的 研究，1.上顎洞について。菌科学報 74: 186018891974.

42) 堀正幸, 高橋栄明, 他：2 回骨標識時に観察 された 2 重骨標識の種類。高橋栄明編; 骨形態 ハンドブック第1版, 西村書店, 新渴, 1983, 147-153真。 